\title{
mHealth Interventions to Promote Anti-Retroviral Adherence in HIV: Narrative Review
}

Stephen B Lee ${ }^{1,2}$, MD, FRCPC; Joanne Valerius ${ }^{2}$, PhD

${ }^{1}$ Department of Medicine, Division of Infectious Diseases, University of Saskatchewan College of Medicine, Regina, SK, Canada

${ }^{2}$ Department of Medical Informatics and Clinical Epidemiology, Oregon Health and Science University, Portland, OR, United States

Corresponding Author:

Stephen B Lee, MD, FRCPC

Department of Medicine, Division of Infectious Diseases

University of Saskatchewan College of Medicine

Regina General Hospital, Unit 4E

Regina, SK, S4P 0W5

Canada

Phone: 13067664247

Email: leestephenz@gmail.com

\section{Related Article:}

This is a corrected version. See correction statement in: https://mhealth.jmir.org/2020/9/e24250/

\section{Abstract}

Background: Antiretrovirals (ARVs) are key in the management of HIV. Although no cure exists, ARVs help patients live healthy lives and prevent transmission to others. Adherence to complex regimens is paramount to outcomes and in avoiding the emergence of drug-resistant viruses. The goal of therapy is to reach an undetectable viral load. However, adherence is a common problem, stemming from issues such as mental health, chaotic home situations, and busy work schedules. Mobile health (mHealth) represents a new approach in improving medication adherence, and multiple studies have been performed in this area.

Objective: This study aims to review the current implementation of mHealth in the management of HIV among different groups of patients.

Methods: We used PubMed, Academic Search Elite, and 1 journal database with various search terms to review the current implementation of mHealth in HIV care.

Results: Titles and abstracts were screened, and 61 papers were identified and fully reviewed. The literature was divided into lower- and higher-income nations, as defined by the United Nations. A total of 20 studies with quantitative results were identified, with 10 being text- and SMS-based interventions (the majority of these being in lower-income countries) and 8 being smartphone-based apps (primarily in higher-income countries). The majority of these studies determined whether there was an effect on adherence or biochemical parameters (viral load and CD4 count). Various qualitative studies have also been conducted, and many have focused on determining the specific design of interventions that were successful (frequency of messaging, types of messages, etc) as well as priorities for patients with regard to mHealth interventions.

Conclusions: There seems to be a role of mHealth in the management of HIV in lower-income nations; however, the optimal design of an intervention needs to be delineated. In higher-income countries, where the 2 significant risk factors were injection drugs and men who have sex with men, the benefit was less clear, and more research is needed.

(JMIR Mhealth Uhealth 2020;8(8):e14739) doi: $\underline{10.2196 / 14739}$

\section{KEYWORDS}

mHealth; HIV; antiretroviral; adherence; mobile phone 


\section{Introduction}

\section{Background}

HIV remains to be a significant public health concern, causing an estimated 770,000 deaths worldwide, with significant mortality from poorly managed disease, even in developed nations [1,2]. Particularly in the developing world, there is significant morbidity with $79.1 \%$ of HIV prevalence centered in Africa $(25,700,000$ people) and Southeast Asia (3,500,000 people) $[3,4]$.

The burden of this disease is not only health related but also impacts economics and development. A large proportion of deaths from HIV occurs in young and middle-aged adults; the same group of people who raise children, are caretakers, work, and teach future generations. Especially in lower-income countries, families who have had a death from HIV cope by pulling children out of school, reducing food intake, or using up agricultural resources prematurely [5]. In addition, although first-line antiretrovirals (ARVs) cost US $\$ 80$ per year, the cost of second- and third-line regiments (used with drug resistance) may be as high as US \$2200 per year [6].

Despite all these bleak consequences, studies have shown that with adherence to ARV therapy, a patient aged 20 years could expect an additional 43.3 years of life [7]. In contrast, those who are not adherent and develop AIDS have a median survival of 12.1 months [8]. Adherence to ARVs is key to prolonging life, improving immune function and quality of life, and preventing transmission [9-14].

Without proper adherence, there is a risk of disease progression or drug resistance. Despite increasing access to ARVs worldwide, adherence is far from perfect [15,16]. One meta-analysis reported adherence at $62 \%$, and studies on subgroups, such as illicit drug users, are as low as $27 \%[17,18]$.

Factors such as psychiatric disorders, cognitive impairment, social stigma, substance abuse, and volatile housing can prevent optimal adherence [19,20]. Burch et al [21] found clear associations between markers of the social determinants of health and HIV outcomes. Rachlis et al [22] found that substance abuse and unemployment were associated with suboptimal care. The risk of transmission and resistance make it crucial to develop methods for improving adherence to medications. Indeed, international organizations have called for strategies to improve adherence to medication and its importance [23-25].

Consumer informatics, particularly mobile health (mHealth), has shown promise in improving ARV adherence. Indeed, research has shown that patients living with HIV are interested in apps to support HIV self-management, and much past research has been done to support disease management [26,27].

Given the widespread adoption of cellphones (95\% of the population) and smartphones $(77 \%)$ in different parts of the world, mHealth is becoming an important tool to improve care [28]. Furthermore, in North America, access to mobile data and the internet ranges close to $80 \%$, and with expanding mobile computing capabilities, this represents further opportunities [29].

\section{Objectives}

We believe that the major benefits that mHealth could offer would be helping with medication and appointment adherence, improving HIV education, and increasing engagement in care. Some studies have shown promise in improving viral suppression and CD4 count. However, there are existing gaps in current reviews [30]. First, as technology is a rapidly growing field, constantly updated work is needed to summarize developments. Second, and most importantly, people who live with HIV are a diverse group of patients with a variety of challenges, including living in developing countries with poor health infrastructure and having comorbid substance use issues [31-34]. Each of these patient populations has unique characteristics and concerns that may influence care. For instance, access to the internet and smartphones, health care, income, and psychiatric comorbidities could be vastly different in various groups. The majority of existing reviews homogenize and summarize the existing literature as a whole and do not consider the differences in patient populations [35-39]. An intervention may have varying levels of success in each group and likely needs to be tailored to fit unique needs. For instance, a smartphone app for disease education may be successful in college-educated, smartphone-owning patients; however, it may have a vastly different effect on a patient in the developing world without a smartphone or an advanced education. The underlying differences in patient groups need to be considered, and our review groups studies into subgroups and discusses the implications of such differences.

\section{Methods}

\section{Search Strategy}

Two separate databases with peer-reviewed, reputable articles were used, PubMed and Academic Search Elite. All relevant articles reviewed were within the time period of 2010 to 2019.

For PubMed, we used the following search terms: "mHealth AND HIV AND medication adherence," "app AND HIV AND adherence," "smartphone AND app AND HIV AND anti-retroviral adherence," and "mobile phone AND anti-retroviral adherence AND HIV." On reviewing the literature using these search terms, we added the search terms "WelTel" and "CAMPS and retroviral" to capture relevant studies found in the references of the articles retrieved from the initial search.

We used the search terms "mHealth AND HIV AND medication adherence," "mobile phone AND anti-retroviral adherence AND HIV," and "app AND HIV AND adherence" for the Academic Search Elite database search.

Finally, we used the Journal of Medical Internet Research database, a group of journals that focuses on informatics implementations in health care, to identify articles listed under "mHealth for Treatment Adherence."

\section{Inclusion and Exclusion Criteria}

A total of 386 search results were screened using the title or abstracts for relevance, and 61 articles were fully reviewed and are discussed in this study. 
Articles were included if they were experimental in nature (encompassing qualitative or quantitative studies as well as randomized controlled trials [RCTs] or other studies). Study designs included RCTs, case studies, cohort studies, cross-sectional studies, and qualitative studies (focus groups, interviews, observations, and surveys). No age restrictions were set, although the majority of the literature focused on adults and studies were required to have all participants diagnosed with HIV. A significant number of articles were excluded (273/325, $84 \%$ ). Reasons for exclusion were irrelevance to the topic discussed, inclusion of patients not diagnosed with HIV, articles written in a language other than English, reviews rather than original research on this topic, categorization as nonexperimental irrespective of whether qualitative or quantitative (for instance, a commentary of mHealth), or if they were protocols for experiments.

We defined mHealth in this study as any intervention that involved the use of mobile phones, smartphones, or other wireless devices (such as smart pill bottles). Although no formal definition of mHealth exists, this description is in agreement with the World Health Organization [40]. Pilot trials found on literature review were included in our review.

\section{Results}

\section{Overview}

A total of 61 papers were identified from the period of 2010 to 2019. In accordance with the mHealth categories previously described by the United Nations, we categorized apps according to type and found that these apps were focused on either treatment support (reminders) or education [41]. In addition, we categorized apps as either push or pull and as one-way versus dual communication. Interventions that were primarily reminders tended to use push, whereas those that were education used pull (Table 1).
As factors such as technology accessibility, socioeconomic background, and internet or cellular connectivity vary based on geographical location, the authors chose to separate the discussion into studies performed in lower- and higher-income countries. Studies were divided into categories (upper middle and upper vs lower middle and low) as per the definition by the United Nations [42].

The risk factor for HIV acquisition in upper middle- and upper-income countries was primarily men who have sex with men (MSM) or intravenous drug users (IVDU). The majority of these studies were performed in North America (Canada and the United States).

For lower middle- and low-income countries, the majority of these studies were based on the African continent, with some conducted in Asia.

Interventions were text or SMS based, voice message based, or smartphone apps. All work in the lower-income countries consisted of simple text or SMS or voice interventions (7/7, $100 \%$ of quantitative studies) [43-49]. In contrast, in higher-income countries, more of the work included advanced smartphone apps $(8 / 13,62 \%$; Table 1) [50-58]. Although we have summarized the quantitative studies on efficacy in Table 1 , other studies discussed the optimal designs or considerations in intervention development and are reviewed in the following sections.

On an evaluation, using the Oxford Centre for Evidence-Based Medicine's Levels of Evidence, there was a large amount of high-level evidence in developing countries, with many RCTs [59]. On the basis of this, we believe that conclusions regarding efficacy are possible. There is also a high level of evidence (with a large number of RCTs) in higher-income countries; however, there remain some limitations to those studies (Table 1). The authors believe that further work may need to be performed in higher-income countries. 
Table 1. Quantitative studies on the effects of mobile health and ubiquitous Health interventions in HIV management and antiretroviral adherence.

\begin{tabular}{|c|c|c|c|c|c|c|}
\hline $\begin{array}{l}\text { Modes of interven- } \\
\text { tion }\end{array}$ & Patient population & Designs & Effects & $\begin{array}{l}\text { Push (cen- } \\
\text { tral) vs pull } \\
\text { (client) vs } \\
\text { other }\end{array}$ & $\begin{array}{l}\text { One-way } \\
\text { vs dual } \\
\text { communi- } \\
\text { cation }\end{array}$ & App type \\
\hline
\end{tabular}

\section{Text message/SMS based $(n=10)$}

\section{Resource-limited settings $(\mathbf{n}=5)$}

Lester et al Low income, primarily urban popu[43]; WelTel lation in Nairobi who were: Kenya1

1. Starting ARVs ${ }^{\mathrm{a}}$ for the first time

2. >18 years old

3. Daily access to mobile phone.

538 randomized: 273 SMS and 265 control in primary analysis

Pop-Eleches Rural government clinic in Kenya. et al [44]

1. Patients were $>18$ years old

2. Patients were started ARV 3 months earlier

Maduka et al Tertiary care Nigerian hospital, pa[45]; SMS tients who had the following:

and counsel- 1. ARVs for $\geq 3$ months ing

2. History of nonadherence $(<95 \%)$

3. Access to mobile SMS

Haberer et al Rural Southwestern Uganda. [46]

1. Patients were $>18$ years old

2. Patients were initiating ARVs

3. Patients had an own operational cell

4. Patients had 1-2 social supporters

5. Patients were close to hospital

Mbuagbaw Hospital in Yaounde, Cameroon et al [47] with patients who:

1. Are $>21$ years old

2. Owned mobile phone, could read, and text

Had $>1$ month of ARV

Higher-income countries $(\mathbf{n}=\mathbf{5})$

Guo et al Large metropolitan South Chinese [60] hospital.

1. Patients were $>18$ years old

2. Patients had $>1$ month of ARVs

3. Patients were able to read or write
Individually randomized mul- Improved rate of tisite to SMS or control; inter- viral suppression vention was weekly SMS with $\quad(57 \%$ vs $48 \%$, response required within 48 hours; primarily zidovudine or stavudine+lamivu-

dine+efavirenz or nevirapine

720 patients randomized to short daily (70), long daily (72), short weekly (73), and long weekly (74) messages. Data gathered from MEMS ${ }^{\mathrm{b}}$ caps

104 randomized to intervention of monthly adherence counseling and twice weekly ARV (52) or control with no SMS or counseling (52)

Improved adherence of $>90 \%$

(53\% vs $40 \%$;

$P=.03$ ); decreased lapses of $>48$ hours (in the weekly message subgroup; $81 \%$ vs $90 \%$; $P=.03$ )

Improved self-reported adherence (76.9\% vs $55.8 \%$; $P=.02)$; improved CD4 (193-575 cells/mL vs 131 361.5 cells $/ \mathrm{mL}$; $P=.007)$

63 patients who were randomized to scheduled SMS and

RTAM $^{\mathrm{c}}$ (21), triggered SMS from RTAM (20), or RTAM only (21); the scheduled SMS group was daily for 1 month and weekly for 2 months, followed by reminders triggered by late or missed doses. SMS was also sent to social supporters if there was no signal $>48$ hours; triggered SMS was sent only in response to late or missed doses

200 patients randomized to weekly SMS developed from focus groups that were varied, contemporary (eg, Season's Greetings), with a call back number (101) vs usual care (99)

62 primarily nonheterosexual males who were randomized to weekly SMS and reminders for ARVs and exercise with WeChat educational materials sent 3 times per month (31) or control (31)

\section{Improved adher-} ence $(91 \%$ vs $79 \%$ vs $79 \% ; P=.04)$; vs 11 vs 11 for 48 4 at 96 hours; $\mathrm{VL}^{\mathrm{d}}$ suppression medications

\begin{tabular}{|c|c|}
\hline Push & Dual \\
\hline
\end{tabular}

$\begin{array}{ll}\text { Push One way } & \text { Diagnostic } \\ & \text { and treat- } \\ & \text { ment sup- } \\ & \text { port (re- } \\ & \text { minder) }\end{array}$

Push Dual Diagnostic and treatment support (reminder) decreased lapses ( 7 hours and 1 vs 3 vs $P=.02$ ); no significant differences in Other (on
arm was
push with
scheduled
messages,
another
arm was
triggered
by smart
pill bottle)

One way Diagnostic and treatment support (reminder)

No significant dif- Push Dual Diagnostic and treatment support (reminder)

No significant dif- Push Dual Diagnostic ference in CD4 and treatcounts or missed ment supminder) 


\begin{tabular}{|c|c|c|c|c|c|c|}
\hline $\begin{array}{l}\text { Modes of interven- } \\
\text { tion }\end{array}$ & Patient population & Designs & Effects & $\begin{array}{l}\text { Push (cen- } \\
\text { tral) vs pull } \\
\text { (client) vs } \\
\text { other }\end{array}$ & $\begin{array}{l}\text { One-way } \\
\text { vs dual } \\
\text { communi- } \\
\text { cation }\end{array}$ & App type \\
\hline $\begin{array}{l}\text { Moore et al } \\
{[61] ; \text { SMS }} \\
\text { for adher- } \\
\text { ence and } \\
\text { drug use, } \\
\text { iTAB }\end{array}$ & $\begin{array}{l}\text { Pilot at UCSD }{ }^{\mathrm{e}} \text { whose patients: } \\
\text { 1. Were }>18 \text { years old } \\
\text { 2. Had DSM-IV-TR }{ }^{\mathrm{f}} \text { diagnosis of } \\
\text { methamphetamine abuse or } \\
\text { dependence or self-reported } \\
\text { use within } 45 \text { days } \\
\text { 3. Were willing to participate in } \\
\text { study components }\end{array}$ & $\begin{array}{l}75 \text { randomized to iTAB, } \\
\text { which were daily personalized } \\
\text { texts built from focus groups } \\
\text { and focused on responsibility } \\
\text { to others, self-esteem, nonad- } \\
\text { herence risks, harm reduction, } \\
\text { reminders, spirituality, celebra- } \\
\text { tion of health, and disease } \\
\text { control (50) vs control (25). } \\
\text { Also assessed metham- } \\
\text { phetamine use with daily texts }\end{array}$ & $\begin{array}{l}\text { No significant dif- } \\
\text { ference in adher- } \\
\text { ence (measured by } \\
\text { MEMS caps); few- } \\
\text { er metham- } \\
\text { phetamine use days } \\
(P=.05)\end{array}$ & Push & Dual & $\begin{array}{l}\text { Diagnostic } \\
\text { and treat- } \\
\text { ment sup- } \\
\text { port (re- } \\
\text { minder) }\end{array}$ \\
\hline $\begin{array}{l}\text { Ingersoll et } \\
\text { al [51]; SMS } \\
\text { including ad- } \\
\text { herence, } \\
\text { mood, and } \\
\text { substance } \\
\text { use }\end{array}$ & $\begin{array}{l}\text { Pilot study from } 2 \text { outpatient clinics } \\
\text { in Virginia serving mainly nonurban } \\
\text { and rural, primarily male and white, } \\
\text { patients who: } \\
\text { 1. Were }>18 \text { years old } \\
\text { 2. Had an active prescription for } \\
\text { ARVs } \\
\text { 3. Had }<95 \% \text { adherence in the } \\
\text { past } 2 \text { weeks } \\
\text { Consumed illicit drugs or had } \\
\text { a risky level of drinking within } \\
\text { 30 days } \\
\text { Had good command of English }\end{array}$ & $\begin{array}{l}63 \text { patients randomized to } \\
\text { daily texts on medications, } \\
\text { twice daily mood texts, and } \\
\text { daily substance use texts elic- } \\
\text { iting responses from patients } \\
\text { (33) or usual care (30) }\end{array}$ & $\begin{array}{l}\text { No significant dif- } \\
\text { ference in propor- } \\
\text { tion of missed vis- } \\
\text { its }(P=.12) \text {; no dif- } \\
\text { ference in sub- } \\
\text { stance use days; } \\
\text { improved adher- } \\
\text { ence }(66 \%-85 \% \text { vs } \\
62 \%-71 \% ; P=.04)\end{array}$ & Push & Dual & $\begin{array}{l}\text { Diagnostic } \\
\text { and treat- } \\
\text { ment sup- } \\
\text { port (re- } \\
\text { minder) }\end{array}$ \\
\hline $\begin{array}{l}\text { King et al } \\
{[62]}\end{array}$ & $\begin{array}{l}\text { Repeated measures study where pa- } \\
\text { tients recruited from a clinic for } \\
\text { women and families living with HIV } \\
\text { in Vancouver, British Columbia, } \\
\text { who: } \\
\text { 1. Attended a clinic for at least } 1 \\
\text { year } \\
\text { 2. Had CD } 4<500 \text { cells } / \mathrm{mm}^{3} \\
\text { 3. Were detectable VL } 1 \text { year } \\
\text { 4. Wrior } \\
\text { 5. Had a high risk for disengage- } \\
\text { ment }\end{array}$ & $\begin{array}{l}85 \text { enrolled with } 5 \text { lost and } \\
\text { administered intervention, } \\
\text { which was modeled after } \\
\text { WelTelKenya1 with SMS or } \\
\text { texts every Monday asking } \\
\text { "How are you?" requiring a } \\
\text { response from patients within } \\
1 \text { day. If no response, this was } \\
\text { followed-up by further texts } \\
\text { and calls }\end{array}$ & $\begin{array}{l}\text { Mean VL de- } \\
\text { creased from } 1098 \\
\text { copies } / \mathrm{mL} \text { to } 439 \\
\text { copies } / \mathrm{mL} \\
(P=.004) \text {; adher- } \\
\text { ence to ARV }(\mathrm{OR} \\
1.14 ; P<.001) \text {; de- } \\
\text { creased appoint- } \\
\text { ment adherence } \\
(\text { OR } 0.81 ; P=.03)\end{array}$ & Push & Dual & $\begin{array}{l}\text { Diagnostic } \\
\text { and treat- } \\
\text { ment sup- } \\
\text { port (re- } \\
\text { minder) }\end{array}$ \\
\hline $\begin{array}{l}\text { Rana et al } \\
{[63]}\end{array}$ & $\begin{array}{l}\text { Patients recruited from Rhode Island } \\
\text { clinic providing HIV services, pri- } \\
\text { marily white, and } \mathrm{MSM}^{\mathrm{i}} \text { as a risk } \\
\text { factor with patients who: } \\
\text { 1. Were } \geq 18 \text { years } \\
\text { 2. Had a cell phone capable of } \\
\text { texting } \\
\text { 3. Were newly engaged in care } \\
\text { within } 1 \text { year or re-engaging } \\
\text { after a lapse of }>1 \text { year or at } \\
\text { risk for nonadherence }\end{array}$ & $\begin{array}{l}32 \text { patients enrolled, with } 20 \\
\text { completing study (exclusions } \\
\text { were due to death, incarcera- } \\
\text { tion, transferal of care, or no } \\
\text { response) given a daily bidi- } \\
\text { rectional texting intervention }\end{array}$ & $\begin{array}{l}\text { Improved VL sup- } \\
\text { pression }(P=.002)\end{array}$ & Push & Dual & $\begin{array}{l}\text { Diagnostic } \\
\text { and treat- } \\
\text { ment sup- } \\
\text { port (re- } \\
\text { minder) }\end{array}$ \\
\hline
\end{tabular}

\section{Smartphone or computer apps $(n=8)$}




\begin{tabular}{|c|c|}
\hline Modes of interven- & Patient population \\
\hline $\begin{array}{l}\text { Venter et al } \\
{[54] \text {; lab re- }} \\
\text { sults, ap- } \\
\text { pointment } \\
\text { reminders, } \\
\text { disease infor- } \\
\text { mation }\end{array}$ & $\begin{array}{l}\text { Multisite } \mathrm{RCT}^{\mathrm{h}} \text { in the inner city of } \\
\text { Johannesburg, South Africa ( } 1 \\
\text { community health center, } 3 \text { clinics, } \\
1 \text { tertiary care hospital) with patients } \\
\text { who: } \\
\text { 1. Were }>18 \text { years old } \\
\text { 2. Read English or Zulu } \\
\text { 3. Were residents of the area }\end{array}$ \\
\hline
\end{tabular}

Himelhoch $\mathrm{t}$ Pilot study from a Baltimore urban al [50] outpatient HIV clinic whose patients:

Dillingham Study from a clinic in Virginia et al [52] whose patients were:

1. New (within 90 days) HIV diagnosis, returning to care after lapse, or considered elevated risk of nonadherence

2. Fourth grade reading level or better

Horvath et al Pilot study recruited from ads on [53] Grindr from Miami, Orlando, Washington DC, Charlotte, Houston, and New Orleans as well as flyers or cards from organizations and clinics serving the targeted population. Patients were:

1. Male and MSM within 5 years

2. A US resident

3. Currently taking ARVs

4. Reporting suboptimal adherence

5. The use of illicit stimulants (eg, methamphetamines, cocaine, ecstasy, amphetamines) within 6 months

6. Owning an iPhone or Android phone

\section{Dworkin et Patients in Chicago who were:} al [55]

1. Aged 18-34 years old

2. On ARVs for $>3$ months

3. Owning an Android smartphone

4. Scheduled for a blood draw or visit during 3 months after baseline assessment

5. African American MSM
Designs

Effects

353 randomized to

SmartLink, which provided appointment reminders, information about lab tests, ARV adherence and HIV info, and CD4 and VL results (181) as well as control (172)

30 patients randomized to the Heart2HAART app giving medication reminders; information regarding adherence; ecological momentary for side effects, depression, and cravings for drug use and tailored education; recommendation; and encouragement (20) vs control of smartphone only (10)
77 enrolled in study primarily male, slightly less than half

MSM given PositiveLinks iteratively designed user-centered app with tailored resources, queries of mood, stress, adherence; appointment reminders, and community forum

90 patients randomized to APP+ for MSM who use stimulants, giving informational material, a playable storyline of a fictional HIV + character, and a tool to track personal adherence (45) vs control (45)

\section{3 patients enrolled, with 11} lost to follow-up, given avatar conversational agent intervention on mobile phones
No significant dif- Push ference in adherence

One way Diagnostic and treatment support (reminder) and education and awareness

Improved retention Pull in care at 12 months $(P<.001)$; improved constant visits $(P<.001)$; improved CD4 count $(P<.001)$; improved VL suppression $(P \leq .001)$

Temporary signifi- Pull cant improvement in self-reported adherence $(P=.04)$; no significant difference in substance use
Dual Diagnostic and treat- ment sup- port (re- minder) and educa- tion and awareness
One way Education and aware- ness

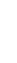

\begin{tabular}{|c|c|c|c|}
\hline Effects & $\begin{array}{l}\text { Push (cen- } \\
\text { tral) vs pull } \\
\text { (client) vs } \\
\text { other }\end{array}$ & $\begin{array}{l}\text { One-way } \\
\text { vs dual } \\
\text { communi- } \\
\text { cation }\end{array}$ & App type \\
\hline $\begin{array}{l}\text { No significant dif- } \\
\text { ference in adher- } \\
\text { ence; improved } \\
\text { linkage to care in } \\
\text { the } 18 \text { - to } 30 \text {-year- } \\
\text { old subgroup ( } 20 \% \\
\text { increase, } P=.02)\end{array}$ & Push & One way & $\begin{array}{l}\text { Diagnostic } \\
\text { and treat- } \\
\text { ment sup- } \\
\text { port (re- } \\
\text { minder) } \\
\text { and educa- } \\
\text { tion and } \\
\text { awareness }\end{array}$ \\
\hline $\begin{array}{l}\text { No significant dif- } \\
\text { ference in adher- } \\
\text { ence }\end{array}$ & Push & One way & $\begin{array}{l}\text { Diagnostic } \\
\text { and treat- } \\
\text { ment sup- } \\
\text { port (re- } \\
\text { minder) } \\
\text { and educa- } \\
\text { tion and } \\
\text { awareness }\end{array}$ \\
\hline
\end{tabular}

\begin{tabular}{|c|c|c|c|}
\hline $\begin{array}{l}\text { Improved adher- } \\
\text { ence (via pill count } \\
\text { adherence }>80 \% \text {; }\end{array}$ & Pull & One way & $\begin{array}{l}\text { Education } \\
\text { and aware- } \\
\text { ness }\end{array}$ \\
\hline
\end{tabular}

\section{Improved adher- $P=.05$ )}

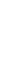

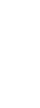

\footnotetext{
Whiteley et al [56]
}

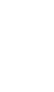




\begin{tabular}{|c|c|c|c|c|c|c|}
\hline $\begin{array}{l}\text { Modes of interven- } \\
\text { tion }\end{array}$ & Patient population & Designs & Effects & $\begin{array}{l}\text { Push (cen- } \\
\text { tral) vs pull } \\
\text { (client) vs } \\
\text { other }\end{array}$ & $\begin{array}{l}\text { One-way } \\
\text { vs dual } \\
\text { communi- } \\
\text { cation }\end{array}$ & App type \\
\hline
\end{tabular}

Patients recruited from the greater Jackson, MS area who were:

1. 14-26 years of age

2. Receiving or starting ARVs

3. Aware of status

4. Detectable VL within 1 month of screening

5. Speaking English

6. Able to consent

Perera et al Patients who were primarily male [57] and homosexual, recruited from the Auckland City Hospital Infectious Diseases Clinic and local HIV support organization who were:

1. On ARVs for at least 6 months

2. Using Android smartphones

Ownby et al Recruitment of patients in Broward [58] County, FL with a large proportion

of $\mathrm{MSM}^{\mathrm{g}}$

\section{Voice calls $(\mathbf{n}=\mathbf{2})$}

\section{Resource-limited settings $(n=2)$}

\begin{tabular}{|c|c|}
\hline $\begin{array}{l}\text { Shet et al } \\
{[48]}\end{array}$ & $\begin{array}{l}1 \text { ambulatory and } 1 \text { private HIV } \\
\text { clinics in India whose patients: }\end{array}$ \\
\hline $\begin{array}{l}\text { HIVIND, in- } \\
\text { teractive au- } \\
\text { tomated } \\
\text { voice all and } \\
\text { reminder } \\
\text { pictorial }\end{array}$ & $\begin{array}{l}\text { 1. Were aged } 18-60 \text { years } \\
\text { 2. Were ARV naïve } \\
\text { 3. Had first-line ARV: (zidovu- } \\
\text { dine or stavudine or teno- } \\
\text { fovir+lamivudine+nevirapine } \\
\text { or efavirenz) }\end{array}$ \\
\hline
\end{tabular}

Rodrigues et Bangalore, South Indian tertiary, al [49] nonprofit private facilities outpatients who:

1. Had access to mobile phones

2. Had $>1$ month on ARVs

3. Had first-line regimens (zidovudine or stavudine+lamivudine+nevirapine or efavirenz)

\author{
66 patients who were primari- \\ ly male, black, and nonhetero- \\ sexual enrolled, with 5 pa- \\ tients lost receiving BattleVi- \\ ro mobile game designed \\ from qualitative user feedback \\ that helped ARV adherence, \\ viral load, and other knowl- \\ edge regarding HIV
}

28 randomized to augmented Increased self-reapps, including graphical representations of ARV concentrations and simulation of immune activity (17) vs norma apps with medication clock only (11)

124 participants recruited in educational intervention, with a final 109 patients analyzed for results

631 educated patients randomized to motivational call with inquiry of adherence requiring response and pictorial SMS (315) or control (316)

Greater decrease in VL $(0.96 \log$ greater decrease in intervention; $P=.04)$; improved adherence $(71 \%$ vs $48 \% ; P=.05$ ) ported adherence via MARS ${ }^{i}$ score (48.93 vs 47.09 ; $P=.03)$; lower VL at 3 months $(1.30$ $\log 10$ vs 1.70 $\log 10 ; P=.02$ )

Improved adherence in subgroups with lower baseline adherence rates (in $<85 \%$ adherence, $P=.04$; in $<80 \%$ adherence $P=.09$ ) difference in adher-
No significant dif- Push Dual ference in viral load; no significant ence
Diagnostic and treatment support (reminder)
Quasi experimental, where 150 primarily male patients were all given automated interactive voice response call and noninteractive neutral picture SMS every week for 6 months and studied at the end of the intervention

\footnotetext{
${ }^{\mathrm{a}} \mathrm{ARV}$ : antiretroviral.

${ }^{b}$ MEMS: medication event monitoring system

${ }^{c}$ RTAM: real-time adherence monitoring.

${ }^{\mathrm{d}} \mathrm{VL}$ : viral load.

${ }^{\mathrm{e} U C S D}$ : University of California at San Diego.

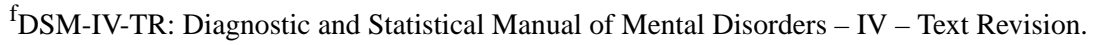

${ }^{\mathrm{g}}$ MSM: men who have sex with men.

${ }^{\mathrm{h}}$ RCT: randomized controlled trial.

${ }^{\mathrm{i}}$ MARS: medication adherence report scale.
} 


\section{Lower-Income Countries Group}

Given the rising rates of cellular access in the developing world, mHealth represents a significant opportunity to improve care [64].

A variety of studies have been conducted on mHealth interventions in the developing world, with a wide range of study methodologies. The quantitative experimental designs (including cohort studies and RCTs) are summarized in Table 1 for ease of comparison. Seven studies with quantitative data were available, with the majority being text- or SMS-based modalities ( 5 studies) and a minority being voice call based (2 studies) [43-49].

Other studies investigated user acceptability and surveyed patient concerns regarding the use of mHealth. A pilot study in rural Uganda by Musiimenta et al [65] enrolled 63 patients and randomized them to a scheduled SMS, triggered SMS (by missed or delayed doses), or no SMS. The feedback received was positive, citing usefulness for motivation, reminders, and social support. However, confidentiality, shared phones, ability to use the phone, and availability of electricity were concerns [65]. Similarly, an explorative study by Lepere et al [66] demonstrated that mHealth was acceptable among people who live with HIV in Cote d'Ivoire, Togo, and Burkina Faso and advocated for its use. Mbuagbaw et al [67] also demonstrated, in a qualitative arm of the CAMPS trial, that these interventions were acceptable, although content, timing, technical challenges, and privacy need to be considered.

\section{Higher-Income Countries Group}

Countries classified as high or high middle income were analyzed. The primary risk factors in these studies were either IVDU or MSM, in agreement with the previous literature $[68,69]$.

Quantitative experimental studies are described in Table 1 [50-58,60-63,70]. In addition, a number of nonquantitative or nonexperimental studies were conducted to investigate the nature of optimal interventions. These are summarized in Table 2 [71-84].

Different studies have investigated aspects of mHealth apps other than efficacy. WelTel was studied in Vancouver, British Columbia, on patients involved with substance abuse using both quantitative and qualitative methodologies [62,84]. One such study was done by Campbell et al [85], who studied WelTelBC1 from an economic perspective on 85 viral load-positive vulnerable patients (defined as substance use and other psychosocial factors), finding that the cost of caring for a highly vulnerable patient was US $\$ 347.74$, whereas the overall median cost was US \$36.72.

Multiple quantitative studies investigated the acceptability of mHealth interventions. In Seattle, 224 patients with HIV were randomized to receive two-way pagers with personalized adherence messages. Of these patients, 55\% identified as gay or lesbian, and the majority were white males. Participants were surveyed for the usefulness of the pager and asked whether they adhered to their medications; $73 \%$ reported liking the pager, $51 \%$ began finding messages annoying, and $48 \%$ believed that the pager did not improve their adherence. The overall response rate was only $42.8 \%$ but declined over 3 months. The self-reported pager adherence was $90.8 \%$ (SD 33\%) compared with the medication event monitoring system showing $53.6 \%$ (SD 37\%) adherence [86].

Similarly, a Peruvian study by Krishnan et al [87] with 359 transgender women or MSM patients asked about mHealth preferences using a 5-point Likert scale. They found an overall positive uptake, with a mean of 3.21 for technological medication reminders and 3.56 for anonymous internet chats to discuss HIV issues.

Other studies, using focus groups and other quantitative study methods, were used to determine how best to deliver mHealth interventions. For instance, Krishnan et al [87] also found that daily messages were preferred in terms of frequency within their study population. In Bangkok, Anand et al [88] interviewed $16 \mathrm{MSM}$ and 2 transgender women. They gathered information on preferences and how to address needs with electronic health. The group found that $39 \%(7 / 18)$ of patients preferred instant messaging and $11 \%(2 / 18)$ preferred phone calls. Of these, $39 \%$ $(7 / 18)$ wanted a private website chat room and $11 \%(2 / 18)$ preferred Skype (Skype Communications) video chats. All patients desired personalized reminder messages; 50\% (9/18) wanted reminders on an instant message app, 17\% (3/18) preferred a stand-alone app, and 33\% (6/18) wanted it as an SMS. The theme that emerged was web based, accessible, and reliable disease information [88].

Work performed in higher-income countries also had diversity in intervention type. For instance, Skrajner et al [89] enrolled a patient with cognitive impairment in a video-conferenced, cognitive-psychosocial program that improved the pill count adherence rate from $75 \%$ to $97.9 \%$ in 1 month $(80 \%$ in $2-3$ months). Similarly, the weCare team, which has done non-HIV work on social media, is currently developing a tailored Facebook, text, and social and sexual networking app-based intervention to help engage care [90]. Hwayoung et al [91] combined an electronic pill bottle, fitness tracker, and phone alerts and found that the pill bottle encouraged adherence and self-management of medications. However, they mentioned that the smart pill bottle was too small to fit all the pills, although they liked how it was easy to open and discrete [91].

Finally, Schnall et al [92] created the mVIP app, which attempted to provide self-care strategies for self-management of different HIV-related symptoms. They found improvements in a variety of symptoms, including anxiety $(P=.001)$, depression $(P=.001)$, neuropathy $(P=.002)$, fevers or chills or sweats $(P=.04)$, and weight loss $(P=.02)$. Results for adherence were mixed, showing improvement only when measuring it via the center for adherence support evaluation adherence index [92]. 
Table 2. Qualitative studies on the priorities and important themes in mobile health interventions.

\begin{tabular}{|c|c|}
\hline Study & Designs \\
\hline Senn et al [71] & $\begin{array}{l}22 \text { African American MSM }{ }^{\mathrm{a}} \text { with HIV in Rochester completed surveys } \\
\text { and qualitative interviews }\end{array}$ \\
\hline $\begin{array}{l}\text { LeGrand et al } \\
{[72,73]}\end{array}$ & $\begin{array}{l}\text { EPIC Allies (University of North Carolina, Duke University) under- } \\
\text { going study now. Game-like app that uses game mechanics and social } \\
\text { networking to improve HIV care. Development study looked at ARV } \\
\text { adherence needs, preferences, and usability testing in young MSM } \\
\text { and transgendered women who have sex with men }\end{array}$ \\
\hline $\begin{array}{l}\text { Dworkin et al } \\
\text { [74] }\end{array}$ & $\begin{array}{l}5 \text { different focus groups composed of African American MSM with } \\
\text { HIV in Chicago iteratively designed a talking avatar app providing } \\
\text { information about disease, improved adherence, and helped with ap- } \\
\text { pointment attendance }\end{array}$ \\
\hline
\end{tabular}

Themes reported by patients

1. Importance of social support

2. Convenience

3. Anonymous and confidential

Castel et al [75] Focus groups and surveys on patients with HIV aged between 13 and 24 year (no delineation as to acquisition) for 3 different game prototypes that were linked with Wisepill dispensers

Morano et al Primarily, 132 African American males enrolled to the Care4Today [76,77] app that helped with medication management and appointments and tracked health, wellness, and goals

Cook et al [78] 37 patients in Colorado studied to determine if messages matched to psychological states were useful. Patients were primarily ethnic minorities and nonheterosexual

Olalla et al [79] Spanish study on 30 patients (15 randomized to app group) who were $>60$ years old. The app offered medical news, reports about HIV, and an anonymous chat between patients

Westergaard et al Recruited patients with HIV who were absent from appointments, [80] had substance use, and had an unsuppressed viral load. Investigated acceptability and uptake of a 2-part intervention that included a smartphone app (delivering tailored interventions and communication) and a peer navigator (psychosocial and logistical support)

Przybyla et al Used app for adult patients with HIV who had been on ARVs for $>3$ [81] months with history of alcohol and a history of at least one recent day of nonadherence. Evaluated feasibility and acceptability of the app

Horvath et al [82] Focus groups for stimulant using MSM with HIV (San Francisco, Minneapolis) and explored app components that were important for continued use and engagement

Rosen et al [83] Focus groups of patients with HIV with a history of substance abuse using the $i H A A R T$ app (which used visual representations of adherence, $\mathrm{VL}^{\mathrm{c}}$, and $\left.\mathrm{CD} 4\right)$

Smillie et al [84] Pilot WelTel study in Vancouver, British Columbia, on patients with substance abuse using a qualitative methodology of semistructured interviews
1. Information about side effects

2. Discrete medication reminders

3. Interactive

4. Engaging

5. Social

6. Informational

7. Customizable

1. Positive impression

2. Importance of confidentiality

3. Motivational over negative messages

4. Customizable

1. Game was feasible and acceptable

2. Customizable, challenging, and user-friendly games

1. Higher education levels, staff support, and possession of smart phone predicted use of app

2. $70.2 \%$ of patients interested in medication reminders

1. Changing messages improved adherence (potentially indicating importance of novelty)

1. No clinical or analytical parameter changes (likely due to short intervention period and small sample)

2. Patients enjoyed the social aspect of the app

3. Analysis of the chat logs showed interested in general health over HIV specifically

4. Most patients seemed to have positive emotions and often mentioned happiness

1. The participants universally commented on the app's usefulness as medication and appointment reminders

2. Some requested alternate apps at the end of the trial

1. Found high report completion rates demonstrating feasibility and acceptability of the app

2. Challenges include those with limited smartphone experience

1. Important features included: low cost, customizable, integrate well into their lives, be engaging, credible, private, and provide appointment and medication reminders

1. Need a balance of requested and provided information 2. Emotions provoked by the app can affect adherence

1. Participants thought app was more useful as means of accessing psychosocial support and health care providers rather than as a reminder or source of information

\footnotetext{
${ }^{a}$ MSM: men who have sex with men.

${ }^{\mathrm{b}} \mathrm{ARV}$ : antiretroviral.

${ }^{\mathrm{c}}$ VL: viral load.
} 


\section{Discussion}

\section{Lower-Income Countries Group}

Many studies have been performed using mHealth to improve adherence, with most in sub-Saharan Africa. Some of the studies were rigorous, large RCTs, such as Kenya WelTel [43]. There were some limitations in other studies where mHealth was not studied independently. For instance, in the study by Maduka et al [45], the effects of adherence counseling and SMS messages were not separated, and in the trial by Haberer et al [46], the role of social supporters was unclear. However, most of the studies indicate an improvement in adherence and VL (Table 1) $[43-46,48,49]$. Furthermore, it seems that mHealth represents a cost-effective intervention compared with the alternatives, with 1 study showing that a nurse could manage 1000 patients per week [43].

Although most studies found benefits, there is a gap in the literature regarding the design of a successful intervention. It was found that daily messages were not optimal, habituation likely being a significant factor [43-47]. Pop-Eleches et al [44] found that weekly interventions were more effective than daily interventions and long versus short messages made no difference, potentially reflecting that the messages were used more as reminders.

Most other successful interventions agreed with tapering schedules, twice weekly messaging in Nigeria, weekly WelTel Kenya1 messages, and the weekly South Indian study $[43,45,46,49]$. Another variable was message interactivity and content. On the basis of the existing literature, it is unclear if the interactivity of messages is important. In terms of content, Pop-Eleches et al [44] showed that a motivational message "This is your reminder. Be strong and courageous, we care about you" was not better than a generic impersonal message. These findings potentially indicate that an interactive or customized message does not negate the effects of habituation. Further work is necessary to determine the exact type of message that generates the maximal benefit.

Cultural contexts likely play a role in feasibility, and caution should be exercised when extrapolating results to different locations. Different views on health care, HIV stigma, baseline demographics, and cultural or religious views could be important when designing an intervention. The HIVIND study illustrates this, with high baseline adherence further boosted by the Hawthorne effect [48].

These studies collectively show a role for mHealth in improving HIV care in low-income or lower middle-income nations; however, we still need to delineate the best design. A less-than-daily message frequency seems to be optimal; however, interactivity and content need to be considered. Geographical and cultural differences may also affect efficacy.

\section{Higher-Income Countries Group}

The major risk factor for HIV in higher-income countries was either IVDU or MSM [93-98]. Although in higher-income countries different factors were identified in HIV management compared with lower-income countries, optimizing adherence is still the key.
In those with IVDU as a risk factor, compliance is important as it has implications for disease transmission. Finding meaningful interventions to improve adherence is crucial as there are higher rates of drug use in patients with $\mathrm{HIV}+$, and these patients often face barriers to adherence [20,99].

However, there are a series of unique challenges for these patients that have implications in implementation and interpretation of studies. An inherent difficulty in studies performed on patients with a history of substance misuse is their heterogeneity, with a variety of substances used, including alcohol, marijuana, cocaine, amphetamines, and opioids. Prolonged use of drugs such as methamphetamines can cause psychotic episodes, resulting in more chaotic lives than other addictive substances [100,101]. Opioids have substitution agents that represent an opportunity for frequent, recurrent health care interaction in dispensing [102]. An intervention efficacious in one group may not be efficacious in another.

In addition, a variety of barriers exist that confound the ability of mHealth interventions to help with adherence. These include unstable financial and housing situations as well as psychiatric comorbidities [103]. Some of these barriers may limit the ability for any intervention to be beneficial without first addressing them.

The majority of the interventions studied in patients with substance misuse were text or SMS based, whereas those focusing on populations with MSM as the major risk factor had more advanced smartphone apps (Table 1) [50-58,60-63]. A potential explanation is the financial resources required for a smartphone and an accompanying plan, which supports the need for stable financial situations before a successful intervention.

Overall, across risk groups in higher-income countries, there seemed to be a theme of advanced mHealth interventions (using apps, social media, and game-like interventions). Examples in our review included EPIC Allies, the talking avatar, and the weCare interventions that contrasted mainly to call and text-related interventions in lower-income countries [72-74,90]. This could potentially be explained by the availability of smartphones and internet connectivity in higher-income countries [28,29].

Regardless of risk factors, a limitation of many of these individual studies was the small sample size. For instance, the iTAB study only showed an effect on methamphetamine use, but as this factor could contribute to nonadherence, a larger sample size may have had an effect on adherence [61].

In addition, studies outside North America should be interpreted with caution if implemented in North America, as many different considerations exist. For instance, different regions of the world preferentially use different messaging apps [104]. These may have different functions and capabilities. Certainly, further work is required [105,106].

Design-related studies indicated the themes that interventions should be customizable, provide disease information, and maintain confidentiality [71-84]. A reminder intervention seems to be acceptable in the patients studied $[76,77,80,82]$. The role of applications as a conduit for health care support was also emphasized [71,84].

JMIR Mhealth Uhealth 2020 | vol. 8 | iss. 8 | e14739| p. 10 (page number not for citation purposes) 
A reasonable conclusion from the totality of the data is that there is a role in improving adherence in higher-income countries, but specific nuances need to be considered on a case-by-case basis. There are limitations affecting the ability to make conclusions, including small sample sizes, heterogeneous populations, and heterogeneous interventions $[53,54,60,62,80-82,88]$.

\section{Conclusions}

This study attempted to review the existing literature on mHealth in HIV adherence, divided the literature to the largest subgroups for which evidence was found, and discussed existing studies with each of these groups as specific contexts.

On the basis of an evaluation of both the results and the quality of evidence available, we believe a clear role for mHealth interventions in developing countries exists; however, further work is needed before a final conclusion can be made in the higher-income countries, where the 2 main subgroup risk factors were MSM and IVDU. In addition, a gap in the literature in all
3 groups is the exact nature of interventions (optimal message frequency, content, and intervention themes).

In addition, as demonstrated by the variety and scope of interventions in our review, there is a difference between digital and mobile access, with some groups having the hardware and connectivity to access advanced apps such as smartphone apps, whereas other groups simply have mobile access and can only access text or SMS or voice call interventions.

Our review of the literature provides an optimistic outlook on the role of mHealth in improving HIV care; however, there are limitations to our work. Our narrative, compared with a systematic methodology, provides a broad and comprehensive overview of the subject area but does not have the stringent inclusion and exclusion criteria of a systematic review. However, our review provides a broad view of the subject and identifies specific focus areas for future systematic reviews. Specific areas of future work include better delineation of the efficacy of different types of interventions in higher-income countries and in specific risk groups within higher-income countries.

\section{Conflicts of Interest}

None declared.

\section{References}

1. Global Health Observatory (GHO) Data: Number of Deaths Due to HIV/AIDS. World Health Organization. 2019. URL: https://www.who.int/gho/hiv/epidemic status/deaths text/en/ [accessed 2020-01-11]

2. Croxford S, Kitching A, Desai S, Kall M, Edelstein M, Skingsley A, et al. Mortality and causes of death in people diagnosed with HIV in the era of highly active antiretroviral therapy compared with the general population: an analysis of a national observational cohort. Lancet Public Health 2017 Jan;2(1):e35-e46 [FREE Full text] [doi: 10.1016/S2468-2667(16)30020-2] [Medline: 29249478]

3. Prevalence of HIV Among Adults Aged 15 to 49, 2017 by WHO Region. World Health Organization. 2017. URL: https:/ /www.who.int/gho/hiv/hiv 013.png?ua=1 [accessed 2019-03-10]

4. Number of Deaths Due to HIV/AIDS: Estimates by WHO Region. World Health Organization. 2019. URL: https://www. who.int/gho/hiv/epidemic status/deaths text/en/ [accessed 2019-05-16] [WebCite Cache ID 78QBZ5HZn]

5. Preparing for the Future of HIV/AIDS in Africa: A Shared Responsibility. The National Academies Press. 2011. URL: https://www.nap.edu/catalog/12991/preparing-for-the-future-of-hivaids-in-africa-a-shared [accessed 2020-01-20]

6. Confronting the HIV/AIDS Deadly Pandemic. Médecins Sans Frontières (MSF) International. 2019. URL: https://www. msf.org/hivaids [accessed 2019-05-16] [WebCite Cache ID 78QBnp636]

7. Teeraananchai S, Kerr S, Amin J, Ruxrungtham K, Law M. Life expectancy of HIV-positive people after starting combination antiretroviral therapy: a meta-analysis. HIV Med 2017 Apr;18(4):256-266 [FREE Full text] [doi: 10.1111/hiv.12421] [Medline: 27578404]

8. Yarchoan R, Venzon DJ, Pluda JM, Lietzau J, Wyvill KM, Tsiatis AA, et al. CD4 count and the risk for death in patients infected with HIV receiving antiretroviral therapy. Ann Intern Med 1991 Aug 1;115(3):184-189. [doi: 10.7326/0003-4819-115-3-184] [Medline: 1676252]

9. Guidelines for the Use of Antiretroviral Agents in Adults and Adolescents with HIV. AIDSinfo. 2019. URL: https://aidsinfo. nih.gov/guidelines/html/1/adult-and-adolescent-arv/10/initiation-of-antiretroviral-therapy [accessed 2019-05-16] [WebCite Cache ID 78QAAmKdR]

10. Le T, Wright EJ, Smith DM, He W, Catano G, Okulicz JF, et al. Enhanced CD4+ T-cell recovery with earlier HIV-1 antiretroviral therapy. N Engl J Med 2013 Jan 17;368(3):218-230 [FREE Full text] [doi: 10.1056/NEJMoa1110187] [Medline: 23323898]

11. INSIGHT START Study Group, Lundgren JD, Babiker AG, Gordin F, Emery S, Grund B, et al. Initiation of antiretroviral therapy in early asymptomatic HIV infection. N Engl J Med 2015 Aug 27;373(9):795-807 [FREE Full text] [doi: 10.1056/NEJMoa1506816] [Medline: 26192873]

12. Langford SE, Ananworanich J, Cooper DA. Predictors of disease progression in HIV infection: a review. AIDS Res Ther 2007 May 14;4:11. [doi: 10.1186/1742-6405-4-11] [Medline: 17502001] 
13. Samji H, Cescon A, Hogg RS, Modur SP, Althoff KN, Buchacz K, North American AIDS Cohort Collaboration on Research and Design (NA-ACCORD) of IeDEA. Closing the gap: increases in life expectancy among treated HIV-positive individuals in the United States and Canada. PLoS One 2013;8(12):e81355 [FREE Full text] [doi: 10.1371/journal.pone.0081355] [Medline: 24367482]

14. Lohse N, Obel N. Update of survival for persons with HIV infection in Denmark. Ann Intern Med 2016 Nov 15;165(10):749-750. [doi: 10.7326/L16-0091] [Medline: 27842400]

15. Yoong D, Bayoumi AM, Robinson L, Rachlis B, Antoniou T. Public prescription drug plan coverage for antiretrovirals and the potential cost to people living with HIV in Canada: a descriptive study. CMAJ Open 2018;6(4):E551-E560 [FREE Full text] [doi: $10.9778 / \mathrm{cmajo} .20180058$ ] [Medline: $\underline{30482757]}$

16. World Health Organization. Access to Antiretroviral Drugs in Low- and Middle-income Countries: Technical Report July 2014. Geneva, Switzerland: World Health Organization; 2014.

17. Ortego C, Huedo-Medina TB, Llorca J, Sevilla L, Santos P, Rodríguez E, et al. Adherence to highly active antiretroviral therapy (HAART): a meta-analysis. AIDS Behav 2011 Oct;15(7):1381-1396. [doi: 10.1007/s10461-011-9942-x] [Medline: 21468660]

18. Iacob SA, Iacob DG, Jugulete G. Improving the adherence to antiretroviral therapy, a difficult but essential task for a successful HIV treatment-clinical points of view and practical considerations. Front Pharmacol 2017;8:831 [FREE Full text] [doi: 10.3389/fphar.2017.00831] [Medline: 29218008]

19. Saracino A, Zaccarelli M, Lorenzini P, Bandera A, Marchetti G, Castelli F, Icona Foundation Study Group. Impact of social determinants on antiretroviral therapy access and outcomes entering the era of universal treatment for people living with HIV in Italy. BMC Public Health 2018 Jul 13;18(1):870 [FREE Full text] [doi: 10.1186/s12889-018-5804-z] [Medline: $\underline{30005709]}$

20. Feldman MB, Kepler KL, Irvine MK, Thomas JA. Associations between drug use patterns and viral load suppression among HIV-positive individuals who use support services in New York City. Drug Alcohol Depend 2019 Apr 1;197:15-21. [doi: 10.1016/j.drugalcdep.2018.12.015] [Medline: $\underline{30743195]}$

21. Burch LS, Smith CJ, Anderson J, Sherr L, Rodger AJ, O'Connell R, et al. Socioeconomic status and treatment outcomes for individuals with HIV on antiretroviral treatment in the UK: cross-sectional and longitudinal analyses. Lancet Public Health 2016 Nov;1(1):e26-e36 [FREE Full text] [doi: 10.1016/S2468-2667(16)30002-0] [Medline: 28299369]

22. Rachlis B, Burchell AN, Gardner S, Light L, Raboud J, Antoniou T, Ontario HIV Treatment Network Cohort Study. Social determinants of health and retention in HIV care in a clinical cohort in Ontario, Canada. AIDS Care 2017 Jul;29(7):828-837. [doi: 10.1080/09540121.2016.1271389] [Medline: 28027668]

23. Chaiyachati KH, Ogbuoji O, Price M, Suthar AB, Negussie EK, Bärnighausen T. Interventions to improve adherence to antiretroviral therapy: a rapid systematic review. AIDS 2014 Mar;28(Suppl 2):S187-S204. [doi: 10.1097/QAD.0000000000000252] [Medline: 24849479]

24. Koester KA, Johnson MO, Wood T, Fredericksen R, Neilands TB, Sauceda J, et al. The influence of the 'good' patient ideal on engagement in HIV care. PLoS One 2019;14(3):e0214636 [FREE Full text] [doi: 10.1371/journal.pone.0214636] [Medline: $\underline{30921440}$ ]

25. Cheever LW. Engaging HIV-infected patients in care: their lives depend on it. Clin Infect Dis 2007 Jun 1;44(11):1500-1502. [doi: 10.1086/517534] [Medline: 17479949 ]

26. Lucero RJ, Frimpong JA, Fehlberg EA, Bjarnadottir RI, Weaver MT, Cook C, et al. The relationship between individual characteristics and interest in using a mobile phone app for HIV self-management: observational cohort study of people living with HIV. JMIR Mhealth Uhealth 2017 Jul 27;5(7):e100 [FREE Full text] [doi: 10.2196/mhealth.7853] [Medline: $\underline{28751298]}$

27. Yi JY, Kim Y, Cho Y, Kim H. Self-management of chronic conditions using mhealth interventions in Korea: a systematic review. Healthc Inform Res 2018 Jul;24(3):187-197 [FREE Full text] [doi: 10.4258/hir.2018.24.3.187] [Medline: 30109152]

28. Mobile Fact Sheet. Pew Research Center. 2019. URL: http://www.pewinternet.org/fact-sheet/mobile/ [accessed 2019-05-16] [WebCite Cache ID 78QCxCcj9]

29. Bauman K. New Survey Questions Do a Better Job Capturing Mobile Use. United States Census. 2019. URL: https://www. census.gov/library/stories/2018/08/internet-access.html [accessed 2019-05-16] [WebCite Cache ID 78QChW6sa]

30. Catalani C, Philbrick W, Fraser H, Mechael P, Israelski DM. Mhealth for HIV treatment \& prevention: a systematic review of the literature. Open AIDS J 2013;7:17-41 [FREE Full text] [doi: 10.2174/1874613620130812003] [Medline: 24133558]

31. HIV Prevention and Control Report. Government of Saskatchewan. 2017. URL: https://www.saskatchewan.ca/government/ government-structure/ministries/health/other-reports/annual-report-archive [accessed 2020-07-24]

32. HIV Surveillance Reports. Centers for Disease Control and Prevention. URL: http://www.cdc.gov/hiv/library/reports/ hiv-surveillance.html [accessed 2020-01-06]

33. Joseph HA, Pan Y, Mendoza M, Harawa NT, Lauby J, Hosek SG, et al. HIV acquisition and transmission potential among African American men who have sex with men and women in three US cities. Arch Sex Behav 2018 Jan;47(1):183-194. [doi: 10.1007/s10508-017-1052-z] [Medline: 29124541] 
34. Beyrer C, Baral SD, van Griensven F, Goodreau SM, Chariyalertsak S, Wirtz AL, et al. Global epidemiology of HIV infection in men who have sex with men. Lancet 2012 Jul 28;380(9839):367-377 [FREE Full text] [doi: 10.1016/S0140-6736(12)60821-6] [Medline: 22819660]

35. Cooper V, Clatworthy J, Whetham J, Consortium E. Mhealth interventions to support self-management in HIV: a systematic review. Open AIDS J 2017;11:119-132 [FREE Full text] [doi: 10.2174/1874613601711010119] [Medline: 29290888]

36. Daher J, Vijh R, Linthwaite B, Dave S, Kim J, Dheda K, et al. Do digital innovations for HIV and sexually transmitted infections work? Results from a systematic review (1996-2017). BMJ Open 2017 Nov 3;7(11):e017604 [FREE Full text] [doi: 10.1136/bmjopen-2017-017604] [Medline: 29101138]

37. Quintana Y, Gonzalez Martorell EA, Fahy D, Safran C. A systematic review on promoting adherence to antiretroviral therapy in HIV-infected patients using mobile phone technology. Appl Clin Inform 2018 Apr;9(2):450-466 [FREE Full text] [doi: 10.1055/s-0038-1660516] [Medline: 29925099]

38. Wang Z, Zhu Y, Cui L, Qu B. Electronic health interventions to improve adherence to antiretroviral therapy in people living with HIV: systematic review and meta-analysis. JMIR Mhealth Uhealth 2019 Oct 16;7(10):e14404 [FREE Full text] [doi: 10.2196/14404] [Medline: 31621641$]$

39. Mulawa MI, LeGrand S, Hightow-Weidman LB. Ehealth to enhance treatment adherence among youth living with HIV. Curr HIV/AIDS Rep 2018 Aug;15(4):336-349 [FREE Full text] [doi: 10.1007/s11904-018-0407-y] [Medline: 29959649]

40. World Health Organization. MHealth: New Horizons for Health Through Mobile Technologies. Geneva, Switzerland: World Health Organization; 2011.

41. mHealth for Development: The Opportunity of Mobile Technology for Healthcare in the Developing World. Web Archive. 2011. URL: https://web.archive.org/web/20121203014521/http://vitalwaveconsulting.com/pdf/2011/mHealth.pdf [accessed 2020-05-04]

42. World Economic Situation and Prospects. United Nations. 2020. URL: https://www.un.org/development/desa/dpad/ wp-content/uploads/sites/45/WESP2020 FullReport.pdf [accessed 2020-06-11]

43. Lester RT, Ritvo P, Mills EJ, Kariri A, Karanja S, Chung MH, et al. Effects of a mobile phone short message service on antiretroviral treatment adherence in Kenya (WelTel Kenya1): a randomised trial. Lancet 2010 Nov 27;376(9755):1838-1845. [doi: 10.1016/S0140-6736(10)61997-6] [Medline: 21071074]

44. Pop-Eleches C, Thirumurthy H, Habyarimana JP, Zivin JG, Goldstein MP, de Walque D, et al. Mobile phone technologies improve adherence to antiretroviral treatment in a resource-limited setting: a randomized controlled trial of text message reminders. AIDS 2011 Mar 27;25(6):825-834 [FREE Full text] [doi: 10.1097/QAD.0b013e32834380c1] [Medline: 21252632]

45. Maduka O, Tobin-West CI. Adherence counseling and reminder text messages improve uptake of antiretroviral therapy in a tertiary hospital in Nigeria. Niger J Clin Pract 2013;16(3):302-308 [FREE Full text] [doi: 10.4103/1119-3077.113451] [Medline: 23771450]

46. Haberer JE, Musiimenta A, Atukunda EC, Musinguzi N, Wyatt MA, Ware NC, et al. Short message service (SMS) reminders and real-time adherence monitoring improve antiretroviral therapy adherence in rural Uganda. AIDS 2016 May 15;30(8):1295-1300 [FREE Full text] [doi: 10.1097/QAD.0000000000001021] [Medline: 26760452]

47. Mbuagbaw L, Thabane L, Ongolo-Zogo P, Lester RT, Mills E, Volmink J, et al. The Cameroon mobile phone SMS (CAMPS) trial: a protocol for a randomized controlled trial of mobile phone text messaging versus usual care for improving adherence to highly active anti-retroviral therapy. Trials 2011 Jan 7;12:5 [FREE Full text] [doi: 10.1186/1745-6215-12-5] [Medline: 21211064]

48. Shet A, de Costa A, Kumarasamy N, Rodrigues R, Rewari BB, Ashorn P, HIVIND Study Team. Effect of mobile telephone reminders on treatment outcome in HIV: evidence from a randomised controlled trial in India. Br Med J 2014 Oct 24;349:g5978 [FREE Full text] [doi: 10.1136/bmj.g5978] [Medline: 25742320]

49. Rodrigues R, Shet A, Antony J, Sidney K, Arumugam K, Krishnamurthy S, et al. Supporting adherence to antiretroviral therapy with mobile phone reminders: results from a cohort in South India. PLoS One 2012;7(8):e40723 [FREE Full text] [doi: 10.1371/journal.pone.0040723] [Medline: 22952574]

50. Himelhoch S, Kreyenbuhl J, Palmer-Bacon J, Chu M, Brown C, Potts W. Pilot feasibility study of Heart2HAART: a smartphone application to assist with adherence among substance users living with HIV. AIDS Care 2017 Jul;29(7):898-904. [doi: 10.1080/09540121.2016.1259454] [Medline: 28043176]

51. Ingersoll KS, Dillingham RA, Hettema JE, Conaway M, Freeman J, Reynolds G, et al. Pilot RCT of bidirectional text messaging for ART adherence among nonurban substance users with HIV. Health Psychol 2015 Dec;34S:1305-1315 [FREE Full text] [doi: 10.1037/hea0000295] [Medline: 26651472]

52. Dillingham R, Ingersoll K, Flickinger TE, Waldman AL, Grabowski M, Laurence C, et al. PositiveLinks: a mobile health intervention for retention in HIV care and clinical outcomes with 12-month follow-up. AIDS Patient Care STDS 2018 Jun;32(6):241-250 [FREE Full text] [doi: 10.1089/apc.2017.0303] [Medline: 29851504]

53. Horvath KJ, Lammert S, MacLehose RF, Danh T, Baker JV, Carrico AW. A pilot study of a mobile app to support HIV antiretroviral therapy adherence among men who have sex with men who use stimulants. AIDS Behav 2019 Nov;23(11):3184-3198. [doi: 10.1007/s10461-019-02597-3] [Medline: 31309348] 
54. Venter WD, Fischer A, Lalla-Edward ST, Coleman J, Lau Chan V, Shubber Z, et al. Improving linkage to and retention in care in newly diagnosed hiv-positive patients using smartphones in South Africa: randomized controlled trial. JMIR Mhealth Uhealth 2019 Apr 2;7(4):e12652 [FREE Full text] [doi: 10.2196/12652] [Medline: 30938681]

55. Dworkin MS, Lee S, Chakraborty A, Monahan C, Hightow-Weidman L, Garofalo R, et al. Acceptability, feasibility, and preliminary efficacy of a theory-based relational embodied conversational agent mobile phone intervention to promote HIV medication adherence in young HIV-positive African American MSM. AIDS Educ Prev 2019 Feb;31(1):17-37. [doi: 10.1521/aeap.2019.31.1.17] [Medline: 30742481]

56. Whiteley L, Brown LK, Mena L, Craker L, Arnold T. Enhancing health among youth living with HIV using an iPhone game. AIDS Care 2018;30(sup4):21-33 [FREE Full text] [doi: 10.1080/09540121.2018.1503224] [Medline: $\underline{\text { 30626196] }}$

57. Perera AI, Thomas MG, Moore JO, Faasse K, Petrie KJ. Effect of a smartphone application incorporating personalized health-related imagery on adherence to antiretroviral therapy: a randomized clinical trial. AIDS Patient Care STDS 2014 Nov;28(11):579-586 [FREE Full text] [doi: 10.1089/apc.2014.0156] [Medline: 25290556]

58. Ownby RL, Waldrop-Valverde D, Caballero J, Jacobs RJ. Baseline medication adherence and response to an electronically delivered health literacy intervention targeting adherence. Neurobehav HIV Med 2012 Oct 18;4:113-121 [FREE Full text] [doi: 10.2147/NBHIV.S36549] [Medline: 23293544]

59. OCEBM Levels of Evidence. Centre for Evidence-Based Medicine. 2016. URL: https://www.cebm.net/2016/05/ ocebm-levels-of-evidence/ [accessed 2020-05-07]

60. Guo Y, Xu Z, Qiao J, Hong YA, Zhang H, Zeng C, et al. Development and feasibility testing of an mhealth (text message and WeChat) intervention to improve the medication adherence and quality of life of people living with HIV in China: pilot randomized controlled trial. JMIR Mhealth Uhealth 2018 Sep 4;6(9):e10274 [FREE Full text] [doi: 10.2196/10274] [Medline: $\underline{30181109]}$

61. Moore DJ, Pasipanodya EC, Umlauf A, Rooney AS, Gouaux B, Depp CA, et al. Individualized texting for adherence building (iTAB) for methamphetamine users living with HIV: a pilot randomized clinical trial. Drug Alcohol Depend 2018 Aug 1;189:154-160 [FREE Full text] [doi: 10.1016/j.drugalcdep.2018.05.013] [Medline: 29958127]

62. King E, Kinvig K, Steif J, Qiu AQ, Maan EJ, Albert AY, et al. Mobile text messaging to improve medication adherence and viral load in a vulnerable canadian population living with human immunodeficiency virus: a repeated measures study. J Med Internet Res 2017 Jun 1;19(6):e190 [FREE Full text] [doi: 10.2196/jmir.6631] [Medline: 28572079]

63. Rana AI, van den Berg JJ, Lamy E, Beckwith CG. Using a mobile health intervention to support HIV treatment adherence and retention among patients at risk for disengaging with care. AIDS Patient Care STDS 2016 Apr;30(4):178-184 [FREE Full text] [doi: 10.1089/apc.2016.0025] [Medline: 27028183]

64. Measuring Digital Development: Facts and Figures 2019. International Telecommunication Union. 2019. URL: https:/ /www.itu.int/en/ITU-D/Statistics/Pages/facts/default.aspx [accessed 2019-05-16] [WebCite Cache ID 78Q4g5E0P]

65. Musiimenta A, Atukunda EC, Tumuhimbise W, Pisarski EE, Tam M, Wyatt MA, et al. Acceptability and feasibility of real-time antiretroviral therapy adherence interventions in rural Uganda: mixed-method pilot randomized controlled trial. JMIR Mhealth Uhealth 2018 May 17;6(5):e122 [FREE Full text] [doi: 10.2196/mhealth.9031] [Medline: 29773527]

66. Lepère P, Touré Y, Bitty-Anderson AM, Boni SP, Anago G, Tchounga B, et al. Exploring the patterns of use and acceptability of mobile phones among people living with HIV to improve care and treatment: cross-sectional study in three francophone west African countries. JMIR Mhealth Uhealth 2019 Nov 13;7(11):e13741 [FREE Full text] [doi: 10.2196/13741] [Medline: $\underline{31719023]}$

67. Mbuagbaw L, Bonono-Momnougui RC, Thabane L. Considerations in using text messages to improve adherence to highly active antiretroviral therapy: a qualitative study among clients in Yaoundé, Cameroon. HIV AIDS (Auckl) 2012;4:45-50 [FREE Full text] [doi: 10.2147/HIV.S29954] [Medline: 22570574]

68. HIV - HIV/AIDS Annual Reports. Publications Saskatchewan. 2019. URL: http://www.publications.gov.sk.ca/details.

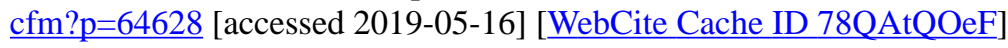

69. Injection Drug Use and HIV Risk. Centers for Disease Control and Prevention. 2019. URL: $\underline{\text { https://www.cdc.gov/hiv/risk/ }}$ idu.html [accessed 2019-05-16] [WebCite Cache ID 78QAw4hlM]

70. Laurence C, Wispelwey E, Flickinger TE, Grabowski M, Waldman AL, Plews-Ogan E, et al. Development of PositiveLinks: a mobile phone app to promote linkage and retention in care for people with HIV. JMIR Form Res 2019 Mar 20;3(1):e11578 [FREE Full text] [doi: 10.2196/11578] [Medline: 30892269]

71. Senn TE, Braksmajer A, Coury-Doniger P, Urban MA, Carey MP. Mobile technology use and desired technology-based intervention characteristics among HIV+ Black men who have sex with men. AIDS Care 2017 Apr;29(4):423-427 [FREE Full text] [doi: 10.1080/09540121.2016.1220479] [Medline: 27535069]

72. LeGrand S, Muessig KE, Platt A, Soni K, Egger JR, Nwoko N, et al. Epic allies, a gamified mobile phone app to improve engagement in care, antiretroviral uptake, and adherence among young men who have sex with men and young transgender women who have sex with men: protocol for a randomized controlled trial. JMIR Res Protoc 2018 Apr 5;7(4):e94 [FREE Full text] [doi: 10.2196/resprot.8811] [Medline: 29622527]

73. LeGrand S, Muessig KE, McNulty T, Soni K, Knudtson K, Lemann A, et al. Epic allies: development of a gaming app to improve antiretroviral therapy adherence among young HIV-positive men who have sex with men. JMIR Serious Games 2016 May 13;4(1):e6 [FREE Full text] [doi: 10.2196/games.5687] [Medline: 27178752] 
74. Dworkin M, Chakraborty A, Lee S, Monahan C, Hightow-Weidman L, Garofalo R, et al. A realistic talking human embodied agent mobile phone intervention to promote HIV medication adherence and retention in care in young HIV-positive African American men who have sex with men: qualitative study. JMIR Mhealth Uhealth 2018 Jul 31;6(7):e10211 [FREE Full text] [doi: 10.2196/10211] [Medline: 30064971]

75. Castel AD, Qasmieh S, Greenberg D, Ellenberger N, Howell TH, Griffith C, et al. Digital gaming to improve adherence among adolescents and young adults living with HIV: mixed-methods study to test feasibility and acceptability. JMIR Serious Games 2018 Oct 15;6(4):e10213 [FREE Full text] [doi: 10.2196/10213] [Medline: 30322838]

76. Care4Today. URL: https://www.care4today.com/ [accessed 2019-12-17]

77. Morano JP, Clauson K, Zhou Z, Escobar-Viera CG, Lieb S, Chen IK, et al. Attitudes, beliefs, and willingness toward the use of mhealth tools for medication adherence in the Florida mhealth adherence project for people living with HIV (FL-MAPP): pilot questionnaire study. JMIR Mhealth Uhealth 2019 Jul 3;7(7):e12900 [FREE Full text] [doi: 10.2196/12900] [Medline: $\underline{\text { 31271150] }}$

78. Cook PF, Carrington JM, Schmiege SJ, Starr W, Reeder B. A counselor in your pocket: feasibility of mobile health tailored messages to support HIV medication adherence. Patient Prefer Adherence 2015;9:1353-1366 [FREE Full text] [doi: 10.2147/PPA.S88222] [Medline: 26491263]

79. Olalla J, de Lomas JM, Márquez E, González FJ, del Arco A, de la Torre J, et al. Experience of using an app in HIV patients older than 60 years: pilot program. JMIR Mhealth Uhealth 2019 Mar 6;7(3):e9904 [FREE Full text] [doi:

10.2196/mhealth.9904] [Medline: 30839281 ]

80. Westergaard RP, Genz A, Panico K, Surkan PJ, Keruly J, Hutton HE, et al. Acceptability of a mobile health intervention to enhance HIV care coordination for patients with substance use disorders. Addict Sci Clin Pract 2017 Apr 26;12(1):11 [FREE Full text] [doi: 10.1186/s13722-017-0076-y] [Medline: 28441962]

81. Przybyla SM, Eliseo-Arras RK, Krawiec G, Gower E, Dermen K. Feasibility and acceptability of a smartphone app for daily reports of substance use and antiretroviral therapy adherence among HIV-infected adults. AIDS Res Treat 2016;2016:9510172 [FREE Full text] [doi: 10.1155/2016/9510172] [Medline: 27610243]

82. Horvath KJ, Alemu D, Danh T, Baker JV, Carrico AW. Creating effective mobile phone apps to optimize antiretroviral therapy adherence: perspectives from stimulant-using HIV-positive men who have sex with men. JMIR Mhealth Uhealth 2016 Apr 15;4(2):e48 [FREE Full text] [doi: 10.2196/mhealth.5287] [Medline: 27084049]

83. Rosen RK, Ranney ML, Boyer EW. Formative research for mhealth HIV adherence: the iHAART app. Proc Annu Hawaii Int Conf Syst Sci 2015 Jan;2015:2778-2785 [FREE Full text] [doi: 10.1109/HICSS.2015.336] [Medline: 26644783]

84. Smillie K, van Borek N, Abaki J, Pick N, Maan EJ, Friesen K, et al. A qualitative study investigating the use of a mobile phone short message service designed to improve HIV adherence and retention in care in Canada (WelTel BC1). J Assoc Nurses AIDS Care 2014;25(6):614-625 [FREE Full text] [doi: 10.1016/j.jana.2014.01.008] [Medline: 24768442]

85. Campbell AR, Kinvig K, Côté HC, Lester RT, Qiu AQ, Maan EJ, et al. Health care provider utilization and cost of an mhealth intervention in vulnerable people living with HIV in Vancouver, Canada: prospective study. JMIR Mhealth Uhealth 2018 Jul 9;6(7):e152 [FREE Full text] [doi: 10.2196/mhealth.9493] [Medline: 29986845]

86. Harris LT, Lehavot K, Huh D, Yard S, Andrasik MP, Dunbar PJ, et al. Two-way text messaging for health behavior change among human immunodeficiency virus-positive individuals. Telemed J E Health 2010 Dec;16(10):1024-1029 [FREE Full text] [doi: 10.1089/tmj.2010.0050] [Medline: 21087122]

87. Krishnan A, Ferro EG, Weikum D, Vagenas P, Lama JR, Sanchez J, et al. Communication technology use and mHealth acceptance among HIV-infected men who have sex with men in Peru: implications for HIV prevention and treatment. AIDS Care 2015;27(3):273-282 [FREE Full text] [doi: 10.1080/09540121.2014.963014] [Medline: 25285464]

88. Anand T, Nitpolprasert C, Kerr SJ, Muessig KE, Promthong S, Chomchey N, et al. A qualitative study of Thai HIV-positive young men who have sex with men and transgender women demonstrates the need for eHealth interventions to optimize the HIV care continuum. AIDS Care 2017 Jul;29(7):870-875. [doi: 10.1080/09540121.2017.1286288] [Medline: 28158952]

89. Skrajner MJ, Camp CJ, Heckman TG, Haberman JL, Kochman A. A fluctuating pattern of over- and under-adherence for HAART: a case study from a videophone intervention project. Clin Gerontol 2011 Feb 23;34(2):144-153 [FREE Full text] [doi: 10.1080/07317115.2011.539520] [Medline: 21607118]

90. Tanner AE, Mann L, Song E, Alonzo J, Schafer K, Arellano E, et al. weCARE: a social media-based intervention designed to increase HIV care linkage, retention, and health outcomes for racially and ethnically diverse young MSM. AIDS Educ Prev 2016 Jun;28(3):216-230 [FREE Full text] [doi: 10.1521/aeap.2016.28.3.216] [Medline: 27244190]

91. Cho H, Flynn G, Saylor M, Gradilla M, Schnall R. Use of the FITT framework to understand patients' experiences using a real-time medication monitoring pill bottle linked to a mobile-based HIV self-management app: a qualitative study. Int J Med Inform 2019 Nov;131:103949 [FREE Full text] [doi: 10.1016/j.ijmedinf.2019.08.009] [Medline: 31561192]

92. Schnall R, Cho H, Mangone A, Pichon A, Jia H. Mobile health technology for improving symptom management in low income persons living with HIV. AIDS Behav 2018 Oct;22(10):3373-3383 [FREE Full text] [doi: 10.1007/s10461-017-2014-0] [Medline: 29299790]

93. Hinkin CH, Barclay TR, Castellon SA, Levine AJ, Durvasula RS, Marion SD, et al. Drug use and medication adherence among HIV-1 infected individuals. AIDS Behav 2007 Mar;11(2):185-194 [FREE Full text] [doi: 10.1007/s10461-006-9152-0] [Medline: 16897351$]$ 
